

\section{Sumário}

I. CRônicas

A Favor de uma Corte Latino-Americana de Justiça ..................................................... 3 Nitish Monebhurrun

Sobre A SOluÇão JUdicial de CONTROvérsias Na AMÉRICA LATINA 7 Lucas Carlos Lima

A Favor de uma Corte Latino-Americana de Justiça - Uma Reação sobre a Legalidade e A Legitimidade De Seu Desenho Institucional............................................................15

Arthur Roberto Capella Giannattasio

O Estudo do Direito Internacional sob uma Nova Perspectiva: Nossa Experiência na Philip C. Jessup International Moot Court Competition............................................20 Ana Vitória Muniz Bokos, Igor Medeiros Maia, Jefferson Seidy Sonobe Hable, Gabriel de Oliveira Borba, Gilda Nogueira Paes Cambraia e Nayara Lima Rocha Da Cruz

Revisión de laudos de arbitrajes de inversión 2019: I Encuentro Anual (Santiago de

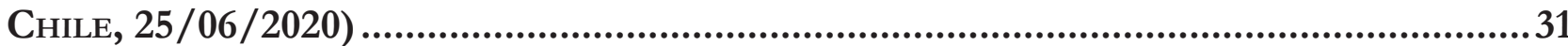
Andrés Delgado Casteleiro e Ivette Esis

II. Dossiê: Populismo e Direito Internacional / Populism and Internatio-

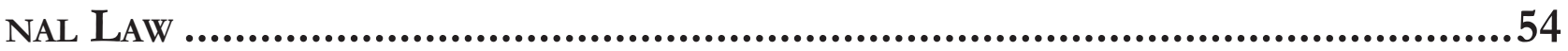

Editorial: Populism and International Law: Global South Perspectives .56 Lucas Lixinski e Fabio Morosini

Editorial: Populismo e Direito Internacional: Perspectivas do Sul Global .61 Lucas Lixinski e Fabio Morosini 
Between Science and populism: the Brazilian Response to COVID-19 from the Perspective of the legal determinants of Global Health

Deisy de Freitas Lima Ventura e Jameson Martins

Populism, ENVIronmental LAW, AND THE POST-PANDEMiC ORDER Alessandra Lehmen

Populism and the Evangelical church in Latin America: how anti-LGBTI forces TRIED TO STOP THE COLOMBIAN PEACE AGREEMENT Julia Assmann de Freitas Macedo e Fabrízio Conte Jacobucci

“Deus EM Davos": o Direito INTERnACIONAL ENTRE REACIONÁRIOS E NEOLIBERAIS NO GOVERNO BOLSONARO 121

Lucas Tasquetto e João Roriz

CHINESE POPULISM IN THE 1920s, EXTRATERRITORIALITY AND INTERNATIONAL LAW 139 Wanshu Cong

CONCEPTUALIZING UNILATERALISM, FRAGMENTATIONISM AND STATISM IN A POPULISM CONTEXT: A RISE OF POPULIST INTERNATIONAL LAW? 162 Wei Shen e Carrie Shu Shang

AUTONOMÍA ADMINISTRATIVA SIN AUTONOMÍA POLÍTICA: LA APLICACIÓN DEL MODELO "UN PAÍS dos SISTEMAs" eN HoNg Kong 186 Juan Enrique Serrano Moreno

III. Artigos sobre outros temas...................................................... 197

Um TWAiler entre nós? As contribuições de Celso Duvivier de Albuquerque Mello PARA O DIREITO INTERNACIONAL (CRÍTICO) NO BRASIL .................................................... 199

Fabio Morosini e Matheus Leichtweis

DEMOCRACIES IN DANGER: ARE JUDICIAL DIALOGUES MEANS TO REFRAIN SETBACKS IN LATIN America?.

Melina Girardi Fachin e Bruna Nowak 


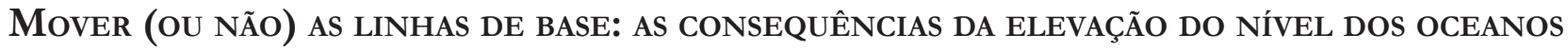
SOBRE AS ZONAS MARÍTIMAS DOS PEQUENOS ESTADOS INSULARES EM DESENVOLVIMENTO E AS ALTERNATIVAS JURÍDICAS PARA REDUZIR SEUS IMPACTOS

Alexandre Pereira da Silva

A mineração em águas profundas no Pacífico 263 Pierre-Jean Bordahandy

Dual Nationality and International Law in times of Globalization. Challenges and Opportunities for Consular Assistance and Diplomatic Protection in RECENT CASES. 288

Walter Arevalo-Ramirez e Robert Joseph Blaise Maclean

Expulsion of aliens: the application of International Law by Chilean Superior Courts 309

Regina Ingrid Díaz Tolosa

O TIPO PENAL BRASILEIRO DE PROMOÇÃo DE MIGRAÇÃO ILEGAL E O PRINCÍPIO DA NÃO CRIMINALIZAÇÃo DA MOBILIDADE HUMANA

Regina Cândido Lima e Silva Santos e Deilton Ribeiro Brasil

INDICADORES TRANSNACIONAIS DE CORRUPÇÃO AMBIENTAL: A OPACIDADE NA TRANSPARÊNCIA INTERNACIONAL

Márcio Ricardo Staffen

SubTRAÇÃo INTERNACIONAL DE CRIANÇAS: ANÁLISE DAS EXCEÇÕES AO RETORNO IMEDIATO DO MENOR À RESIDÊNCIA HABITUAL E CRÍTICA AO ENQUADRAMENTO DA VIOLÊNCIA DOMÉSTICA COMO FLEXIBILIDADE PERMISSIVA

Vivian Daniele Rocha Gabriel

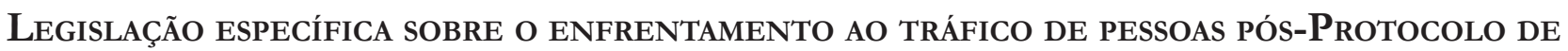
Palermo (2000): análise do Estado de Moçambique 383

Mercia Cardoso de Souza, Guirino Dinis José Nhatave e Francisco Horácio da Silva Frota 
IV. Artigos traduzidos

DIREITO INTERNACIONAL DO RECONHECIMENTO

Emmanuelle Tourme-Jouannet e Tradutor: Ademar Pozzatti Junior

V. RESENHAS

Fabio Costa Morosini, Gabriel Lee Mac Fadden Santos, Valentina Fonseca da Luz e Vinicius Tejadas Maia 


\title{
Dual Nationality and International Law in times of Globalization. Challenges and Opportunities for Consular Assistance and Diplomatic Protection in recent cases
}

\author{
Dupla nacionalidade e direito internacional \\ em tempos de globalização. Desafios e \\ oportunidades de assistência consular e \\ proteção diplomática em casos recentes
}

\author{
Walter Arevalo-Ramirez ${ }^{* *}$ \\ Robert Joseph Blaise Maclean***
}

* Recebido em 23/12/2019

Aprovado em 11/10/2020

** Professor of Public International Law at the Universidad del Rosario Law School in Bogotá, Colombia. PhD summa cum laude, Universidad del Rosario.Visiting researcher at The Hague University of Applied Sciences; the Arctic University of Norway (JCLOS Center for the Law of the Seas) and at the iCourts Center, University of Copenhagen. Tutor in The Hague Academy of International Law. Professor of Public International Law at the Diplomatic Academy of the Ministry of Foreign Affairs (Colombia).Member of the editorial board of the Colombian Yearbook of International Law, Council Member of the Colombian Academy of International Law and Director of the Latin American Network of International Law Journals. E-mail: walter.arevalo@urosario.edu.co

*** Professor of Public International Law at the Universidad del Rosario Law School in Bogotá, Colombia. B.A. Acadia University, Wolfville, Nova Scotia, Canada (1980), LLB Dalhousie University Law School, Halifax, Nova Scotia, Canada (1983), B.Ed. York University, Toronto, Ontario, Canada (2003). E-mail: robert.maclean@urosario.edu.co

\begin{abstract}
This article analyzes the interaction and clashes of the concept of nationality and the concept of diplomatic protection under international law as it may apply to individuals caught in international disputes between states of which they are nationals. The objective of this analytical article is to examine this problem through the lens of the figures of Consular Assistance and Diplomatic Protection. Regarding the methodology, the article is descriptive- analytical and uses legal comparative methodology, since it analyzes both law, treaties and jurisprudence from national and international sources. The article uses case-law analysis and is elaborated within the following structure. Part 1 will deal with the general concept of nationality at international law. Part 2 will examine "Consular Assistance", its source, function and application. Part 3 will examine a separate and distinct facet of international law called "Diplomatic Protection" (as distinguished from "Diplomatic Immunity") and its application to the protection of nationals as well as its weaknesses. Part 4, which develops the original value and final goal of this contribution, consist of an analysis of these particular protective measures within the context of particular cases so as to illustrate the weaknesses of these figures as protective of individuals, the limits of nationality as a shield for individuals caught up in international disputes and the almost "secondclass" nature of dual nationality from an international law perspective. Part 5 as a conclusion will include some observations as to how states may improve the protection they can afford to their nationals abroad.
\end{abstract}

Keywords: Nationality. Diplomatic protection. Dual national. Globalization. Citizenship. International dispute resolution.

\section{Resumo}

Este artigo analisa a interação e os choques entre o conceito de nacionalidade e o conceito de proteção diplomática no âmbito do direito internacional, 
conforme pode ser aplicado a indivíduos envolvidos em disputas internacionais entre Estados dos quais são nacionais. O objetivo deste artigo analítico é examinar esse problema sob a ótica das figuras da Assistência Consular e da Proteção Diplomática. Quanto à metodologia, o artigo é descritivo-analítico e utiliza metodologia jurídica comparativa, uma vez que analisa legislações, tratados e jurisprudências de fontes nacionais e internacionais. $\mathrm{O}$ artigo utiliza a análise da jurisprudência e é elaborado dentro da seguinte estrutura. A Parte 1 tratará do conceito geral de nacionalidade no direito internacional. A Parte 2 examinará "Assistência Consular", sua fonte, função e aplicação. A Parte 3 examinará uma faceta separada e distinta do direito internacional chamada "Proteção Diplomática" (distinta de "Imunidade Diplomática") e sua aplicação à proteção de nacionais, bem como suas fraquezas. A Parte 4, que desenvolve o valor original e o objetivo final desta contribuição, consiste em uma análise dessas medidas de proteção particulares no contexto de casos particulares, de modo a ilustrar as fraquezas dessas figuras como protetoras de indivíduos, os limites da nacionalidade como um escudo para indivíduos envolvidos em disputas internacionais e a natureza quase de "segunda classe" da dupla nacionalidade de uma perspectiva de direito internacional. Como conclusão, a Parte 5 incluirá algumas observações sobre como os estados podem melhorar as proteções que podem oferecer aos seus nacionais no exterior.

Palavras-chave: Nacionalidade. Proteção diplomática. Dupla nacionalidade. Globalização. Cidadania. Resolução de disputa internacional

\section{Introduction}

Recent cases show the challenges that new trends in dual nationality pose to consular assistance and diplomatic protection, once believed as settled institutions in international law. On 1 December 2018 officers of the Royal Canadian Mounted Police and the Canadian Border Services Agency arrested Ms. Meng Wanzhou, a Chinese national and Chief Financial Officer of the Chinese telecommunications giant Huawei as she deplaned at Vancouver International Airport ${ }^{1}$. The arrest

ASSOCIATED PRESS. Huawei: Meng Wanzhou sues Canadian government over arrest. The Guardian, 04 Mar. 2019. Disponível em: https://www.theguardian.com/world/2019/mar/04/ huawei-meng-wanzhou-sues-canadian-government-over-arrest. was in execution of a British Columbia Supreme Court warrant issued following an extradition request from the United States. Extradition was requested in relation to various financial and money laundering charges arising from alleged violations of sanctions against Iran. Though arrests and extraditions are normally quiet and routine, this one gained immediate attention due to Ms. Weng's prominence in China $^{2}$ and the forceful actions taken by China in response. Apart from demanding the immediate release of Ms. Weng, the People's Republic of China, on 10 December 2018, arrested two Canadians working in China. One, Michael Kovrig is a former Canadian diplomat who, at the time of his arrest, was in China working with the International Crisis Group. The other, Michael Spavor was a businessman reportedly working to increase Canadian-North Korean business and cultural ties. Both were arrested for "endangering national security"3 and as of 16 May 2019 news was released that they had both been charged formally with stealing state secrets and passing them to foreign forces. ${ }^{4}$ Accordingly, China has ratcheted up its pressure against Canada in the Meng extradition case.

On 14 January 2019 China upped the ante by bringing another Canadian, Robert Schellenberg, before a court for a sudden retrial. Schellenberg, who had been in custody since 2016, had previously been sentenced to 15 years in custody on drug charges. On re-sentencing, he was sentenced to death. ${ }^{5}$

Kovrig, Spavor and Schellenberg are not the first Canadians to have been caught up in international disputes between China and Canada, or its allies. Ca-

Acesso em: 2 abr. 2019.

The Toronto Star. Disponível em: https://www.thestar. com/vancouver/2019/03/08/why-is-huaweis-meng-wanzhousuch-a-big-deal-shes-treated-like-a-princeling-in-china.html. Acesso em: 2 abr. 2019.

CANADIANS and Chinese justice: a who's who of the political feud so far. The Globe and Mail, Toronto, 15 Jan. 2019 Disponível em: https://www.theglobeandmail.com/world/article-canadians-detained-china-huawei-explainer/. Acesso em: 2 abr. 2019.

CHINA accuses Canadians of espionage. The Washington Post, 16 May 2019. Disponível em: https://www.washingtonpost.com/world/china-formally-accuses-canadiansof-espionage-as-huawei-standoff-intensifies/2019/05/16/ be4b65b6-7790-11e9-ac17-284a66782c41_story.html?utm_ term $=.7 \mathrm{~d} 4292101 \mathrm{bd} 3$. Acesso em: 17 May 2019.

ASSOCIATED PRESS. Chinese court sentences Canadian man to death in drug smuggling case. The Toronto Star, 14 Jan. 2019. Disponível em: https://www.thestar.com/news/ canada/2019/01/14/a-chinese-court-has-sentenced-a-canadianman-to-death-in-a-drug-smuggling-case.html. Acesso em: 2 abr. 2019. 
nadians Kevin and Julia Garratt were detained in 2014 in relation to a similar extradition dispute (with Kevin Garratt eventually spending 19 months in custody). As Canadian nationals Kovrig and Spavor are entitled to consular assistance but, although it has been technically permitted, it has been greatly limited ${ }^{6}$. Even their limited consular assistance stands in stark contrast to the case of Huseyin Celil (detailed below) a Uighur of Chinese birth but a nationalized Canadian. His situation illustrates another serious issue...that of the limitation of rights recognized under international law in Cases involving dual nationals.

Another issue raised by Canada in the case of Mr. Kovrig has to do with the issue Diplomatic Immunity but this is beyond the scope of this paper. ${ }^{7}$

As seen in the case of Zahra Kazemi, an Iranian-born naturalized Canadian citizen ${ }^{8}$ who, at the age of 54 years, died while in custody in Iran not all cases involve China. She was a photojournalist and had traveled to Iran in Spring 2003 to cover student riots happening at the time. Iranian authorities arrested her on 23 June 2003 for taking photos outside a prison in Teheran. She died in custody on 11 July 2003. ' Iranian Vice President Mohammad Ali Abhati acknowledged on 16 July 2003 that, despite earlier representations by the Iranian authorities that she had suffered a stroke, she had in fact died from being beaten. ${ }^{10}$ Iran does not recognize

Then Canadian Ambassador to China, John McCallum informed the Canadian House of Commons on 18 January 2019 that the men, whose whereabouts are unknown, were only allowed consular visits of one-half hour once per month. The Globe and Mail (Toronto) Op cit Note 4. This stands in stark contrast to the treatment of Ms. Weng under the Canadian justice system in which she has had access to a team of lawyers, has been released on bail (with electronic monitoring) and resides in what has been reported to be one of her Vancouver mansions.

Though he was not an accredited diplomat at the time of his arrest, Mr. Kovrig was previously a Canadian diplomat posted to China. Canada has alleged that Mr. Kovrig has been subjected to Chinese interrogation about his duties and actions during his previous period as a diplomat which conduct, says Canada, violates the Vienna Convention on Diplomatic Relations. ZIMONJIC, Peter. Trudeau accuses China of violating diplomatic immunity in arrest of Michael Kovrig. CBC News, 11 Jan. 2019. Disponível em: https:/ www.cbc.ca/news/politics/trudeau-diplomatic-immunity-michaelkovrig-1.4975759. Acesso em: 2 abr. 2019.

She also held French nationality.

9 For a full description of the facts of Ms. Karemi's death please refer to the decision of the Quebec Court of Appeal in Islamic Republic of Iran v. Hashemi 12 Aug. 2012, QCCA 1449. p. 3-5.

10 LIGABO, Ambeyi. Special Rapporteur. U.N. High Commission on Human Rights on the Right to Freedom of Opinion and Expression. Report on Mission to the Islamic Republic of Iran. 12 Jan. 2004 U.N. dual nationality and accordingly throughout the process, Iran took the position that it did not recognize Ms. Kazemi's Canadian nationality and refused to allow Canadian involvement in any investigations, or judicial proceedings in relation to this event. This extended to the refusal to allow the repatriation to Canada of her remains for burial. ${ }^{11}$

These situations and others illustrate that the globalization of today's world means that international disputes and "power politics", once thought to be the rarified subject matter of spats between diplomats arguing over cognac and cigars, can have significant impact on individuals. In such cases, having a nationality is important because it implicitly means having a state that is able to come to such a person's assistance if required ${ }^{12}$. Every diplomatic mission includes a consular mission whose function is to assist nationals in foreign countries. States that do not have embassies in particular countries generally name embassies from other states to whom their nationals may attend if assistance is needed.

This article is about the interaction of nationality and international law as it may apply to individuals caught in international disputes between states of which they are nationals. The article will examine this problem through the lens of the figures of Diplomatic Protection and Consular Assistance. The paper will be developed within the following structure. Part 1 will deal with the general concept of nationality at international law. Part 2 will examine "Diplomatic Protection". Part 3 will examine a separate and distinct facet of international law called Consular Assistance", its source, function and application the protection of nationals as well as its weaknesses. Part 4 will consist of an analysis of these particular protective measures within the context of particular cases to illustrate the limitations of these figures as protective of individuals, the limits of nationality as a shield for individuals caught up in international disputes and the almost "second-class" nature of dual nationality from an international law perspective. Part 5 as a conclusion will include some observations as to how states may improve the protections they can afford to their nationals abroad.

Doc. E/CN.4/62/Add 2, para. 74.

11 Or, as may have been a greater concern from the Iranian perspective, for autopsy.

12 See MCGARVEY-ROSENDAHL, Patricia. A new approach to dual nationality. Hous. J. Int. L., v. 8, p. 305, 1985/1986. 


\section{The concept of nationality under the international law rules on diplomatic protection}

To have a nationality is considered so important under international law that multiple international law instruments characterize it as a "right" or something similar. For example, international law has multiple examples of efforts to eliminate the phenomenon of "statelessness" including the preamble to the Hague Convention on Certain Questions Relating to the Conflict of Nationality Laws ${ }^{13}$ (herein Hague Nationality Convention) of 1930 which provided:

BEING CONVINCED that it is in the general interest of the international community to secure that all its members should recognise that every person should have a nationality and should have one nationality only;

RECOGNISING accordingly that the ideal towards which the efforts of humanity should be directed in this domain is the abolition of all cases both of statelessness and of double nationality ${ }^{14}$;

In 1961, the preamble to the Convention on the Reduction of Statelessness (CRS) ${ }^{15}$ stated it is " [...] desirable to reduce statelessness by international agreement" ${ }^{\prime 16}$. Although the $\mathrm{CRS}$ provides conditions under which States must grant nationality, and, subject to certain conditions, prohibits states from revoking nationality when it would render an individual "stateless"17, it does not contain a general "right" to a nationality. The Universal Declaration of Human Rights ${ }^{18}$, however, does contain a "right" to a nationality, as follows:

Article 15.

(1) Everyone has the right to a nationality.

(2) No one shall be arbitrarily deprived of his

\footnotetext{
13 Hague Convention on Certain Questions Relating to the Conflict of Nationality Laws, 1930.

14 Hague Convention on Certain Questions Relating to the Conflict of Nationality Laws, 1930. Preamble.

15 UNITED NATIONS. Convention on the reduction of statelessness. Treaty Series, v. 989, p. 175. Entered into force 13 Dec. 1975. 5 signatories, 40 parties.

16 UNITED NATIONS. Convention on the reduction of statelessness. Treaty Series, v. 989, p. 175. Entered into force 13 Dec. 1975. 5 signatories, 40 parties. Preamble.

17 UNITED NATIONS. Convention on the reduction of statelessness. Treaty Series, v. 989, p. 175. Entered into force 13 Dec. 1975. 5 signatories, 40 parties. Art 8.1.

18 GA Res. 217A (III) 10 Dec. 1948.
}

nationality nor denied the right to change his nationality. ${ }^{19}$

The International Law Commission, in its Draft Articles on Nationality of Natural Persons in Relation to the Succession of States ${ }^{20}$ included a "Right to Nationality" in Article 1, which would arise in the context of state succession. It provides as follows:

\section{Article 1. Right to a Nationality}

Every individual who, on the date of the succession of States, had the nationality of the predecessor State, irrespective of the mode of acquisition of that nationality, has the right to the nationality of at least one of the States concerned, in accordance with the present draft articles. ${ }^{21}$

Though the United Nations General Assembly has not yet adopted these Draft Articles, they illustrate an evolution in the perception of the individual under international law. Given that they emanate from eminent "publicists" of international law, they carry special weight. They reflect an evolution of a concept of nationality from something within the sovereign right of a State $^{22}$ to confer into something that exists as the right of an individual.

Two other additional instruments containing noteworthy recognitions of this "right" are the International Covenant on Civil and Political Rights ${ }^{23}$, which provides in Article 24 (3) that "Every child has the right to acquire a nationality" ${ }^{24}$ and the European Convention on Nationality 25 provides that "[...] everyone has the right to a nationality."26

\section{GA Res. 217A (III) 10 Dec. 1948. Art 15.}

20 DRAFT Articles on Nationality of Natural Persons in Relation to the Succession of States with Commentaries. Yearbook of the International Law Commission, v. 2, part 2, 1999.

21 DRAFT Articles on Nationality of Natural Persons in Relation to the Succession of States with Commentaries. Yearbook of the International Law Commission, v. 2, part 2, 1999. Art. 1.

22 For an analysis of the challenges of Brazilian domestic laws on nationality, please see: NUNES, Paulo Henrique Faria. Nacionalidade: novas regras, velhos problemas. Revista de Direito Internacional, Brasilia, v. 16, n. 2, p. 225-242, 2019. DOI: http://dx.doi. org/10.5102/rdi.v16i2.5970

${ }^{23}$ International Covenant on Civil and Political Rights, GA Res 2200A (XXI).

${ }^{24}$ International Covenant on Civil and Political Rights, GA Res 2200A (XXI). Art 24 (3).

25 Supra note 14.

26 Supra note 14. Para 4 (a). Art. 4 (c) provides that "[...] no one shall be arbitrarily deprived of his or her nationality." While this is a European Convention, it is clear from the Explanatory Report that the convention is founded on international law. So far as the EU is 
With a nationality comes the expectation and even the right to have the state extend its protections over its citizens, even when abroad. It is perplexing therefore, that international law, which, on the one hand recognizes so firmly the right to acquire a nationality, should, on the other, treat dual nationality as a sort of second-class category.

As regards dual nationals, the role of the state becomes more complicated at the international level. Though migration of peoples is a historical phenomenon, globalization has led to more and more people acquiring dual (or more) nationalities because of birth in one country and living and/or working in another. Children, as well, can acquire dual nationalities on birth because of having parents of different nationalities, depending upon the laws of their place of birth.

People acquiring a second nationality reasonably expect that they will have the rights and benefits that run with being a citizen of the new state. But gaps in international law make it appear that a second nationality is, in some ways "second-class" for the purposes of international law. When disputes arise between states, individuals having nationalities in both states can find themselves caught in the middle. It is at this moment that these "gaps" can manifest themselves. As will be discussed below, some specific current cases provide powerful examples of this problem ${ }^{27}$.

Both the remedy of Diplomatic Protection and the right to consular assistance are framed through reference to nationality. The Vienna Convention on Consular Relations (VCCR) frames its application in terms of nationality. It defines "consular functions" to include the protection in the "receiving state" of the "[...] interests of the sending state and its nationals [...]" (emphasis added), and "[...] helping and assisting nationals, both individuals and corporate, of the sending State;" ${ }^{29}$ VCCR Article 36 permits consular assistance to be provided to "nationals". But who is a national or, more precisely, who qualifies for recognition as a national for purposes of the VCCR?

concerned, it seems, international law prohibits the arbitrary deprivation of an individual's nationality. Article 7 of the 1989 United Nations Convention on the Rights of the Child contains a similar provision.

${ }_{27}^{27}$ That said, there are significant limitations on what a protection a state may accord even a national by birth. Every state may exercise its sovereignty over visitors.

28 VCCR, supra note s Art. 5 (a).

29 VCCR, supra note s Art. 5 (a). Art 5 (e).
Though it is common to use the terms "citizenship" and "nationality" interchangeably, and indeed they mean substantially the same thing, this paper uses the term "nationality" throughout not only because it may be more "internationalist" in tone, but because it the term specifically used in the VCCR. ${ }^{30}$

While "nationality", as a general term, may refer to connections between individuals with a common heritage, Patricia McGarvey-Rosendahl notes that in "[...] international law $[\ldots]$ nationality is narrowly defined and refers to the legal relationship between an individual and a sovereign state." ${ }^{31}$ She says:

Nationality is a reciprocal relationship, as the state gives its protection to the individual and the individual in turn gives his allegiance to the state. ${ }^{32}$

Just as nationality implies that one may expect that your state will protect you, states have an implicit right to determine to whom they will treat as a national for the purposes of extending such protection. An incident of sovereignty is the right to determine who is a national of the state. In the Nottebohm case, a Diplomatic Protection case, the International Court of Justice (I.C.J.) commented:

[...] it is for every sovereign State, to settle by its own legislation the rules relating to the acquisition of its nationality, and to confer that nationality by naturalization granted by its own organs in accordance with that legislation. ${ }^{33}$

Thus, as Peter J. Spiro writes, states have been, “[...] more or less unfettered in formulating their own standards for nationality $[\ldots]^{\prime 34}$

As the ICJ noted in Nottebohm, however, it is one

30 RUBENSTEIN, Kim; ADLER, Daniel. International citizenship: the future of nationality in a globalized world. Ind. Global Legal Stud., v. 7, p. 519, 1999/2000. Another key difference is that the package of rights enjoyed by "nationals" and "citizens" of the same State may be different. For example, Mexico recognizes many Mexicans living outside Mexico as "nationals", but they may lack certain rights of "citizens" such as voting or the right to own land.

31 MCGARVEY-ROSENDAHL, Patricia. A new approach to dual nationality. Hous. J. Int. L., v. 8, p. 305, 1985/1986.

32 MCGARVEY-ROSENDAHL, Patricia. A new approach to dual nationality. Hous. J. Int. L., v. 8, p. 305, 1985/1986.

33 Nottebohm Case (second phase), Judgment of April 6 $6^{\text {th }}, 1955$ : I.C.J. Reports 1955, p.4 at p.20. See also Advisory Opinion No. 4, Tunis-Morocco Nationality Decrees 1923 P.C.I.J. (Ser. B) No. 4 at 24 where it is stated that the issue of nationality falls within the reserved domain of domestic law.

34 SPIRO, Peter. Dual nationality and the meaning of citizenship. Emory Law Journal, v. 46, p. 1411, 1997. (hereinafter referred to as "SPIRO") 
thing for a state to recognize an individual as a national for the purposes of its own domestic law, but a separate question as to whether that recognition extends to the international sphere. In Nottebohm, in which Liechtenstein sought to assert diplomatic protection on behalf of a naturalized subject, the court said that Liechtenstein's recognition of Mr. Nottebohm as its national was not binding internationally. The court said:

It does not depend on the law or the decision of Liechtenstein whether that state is entitled to exercise its protection, in the case under consideration. To exercise protection, to apply to the court, is to place oneself on the plane of international law. It is international law which determines whether a State is entitled to exercise protection and to seise the Court.

The naturalization of Nottebohm was an act performed by Liechtenstein in the exercise of its domestic jurisdiction. The question to be decided is whether that act has the international effect here under consideration. ${ }^{35}$

Thus, for international law purposes, the issue of nationality and its recognition is not determined solely by the domestic law of the nationalizing state. Compliance with international law may or may not be achieved by mere compliance with domestic law.

The acquisition of dual nationalities, and the associated problems, arises from the conflict of national laws regarding the granting of nationality. In general, there are three means by which nationality may be acquired: jus soli (an individual born within a State's territory becomes a citizen of that state), jus sanguinis ${ }^{36}$ (people automatically acquire the nationality of one or both parents) and naturalization. ${ }^{37}$ Special Rapporteur Roberto Córdova, in his 1954 "Report on Dual Nationality" noted: that, at that time,

The main source of double nationality is...the conflict of the principles by virtue of which nationality is acquired at birth. If jus soli were exclusively applied in every State of the world,

\footnotetext{
35 Nottebohm Case, supra note 11, at p. 20-21.

36 For an analysis on the reception of the jus sanguinis criteria under international law, please review: PEREIRA, Hitala Mayara Pereira de Vasconcelos. Da nacionalidade como direito humano: da necessária ampliação das hipóteses de aplicação do critério do jus sanguinis nos casos de adoção internacional. Revista de Direito Internacional, Brasilia, v. 11, n. 2, p. 435-452, 2014/2015. DOI: http:// dx.doi.org/10.5102/rdi.v11i2.3035.

37 MCGARVEY-ROSENDAHL, Patricia. A new approach to dual nationality. Hous. J. Int. L., v. 8, p. 305, 1985/1986.
}

double nationality would never occur. Similarly, if jus sanguinis were the only rule applied, a child would not acquire any other nationality than that of his parents, the nationality of the father prevailing. ${ }^{38}$

This phenomenon is greatly compounded today, over 65 years later, by the vast numbers of people migrating around the world, and the consequent increase in nationalizations. That said, however, the majority of states continue to not recognize dual nationality. ${ }^{39}$

More recently, new means to acquire nationality have been developed and regulated by States, reflecting modern economic needs such as the urgency to attract investors, to diversify the jurisdictions and instruments regarding the protection of investments ${ }^{40}$, or to develop a particular national industry or market. For example, jus doni, also known as citizenship by investment, nationality by investment or economic citizenship, has been adopted by many States around the globe (from the United States to Malta), including what some authors have criticized as "cash for passports" models that grant immediate naturalizations ${ }^{41}$ and don't require residence or other classic requirements that made naturalization a long process before the local authorities, putting into risk the concept of "genuine link" 42 between the citizen and the State.

This phenomenon contributes to the expansion of of dual nationality cases by providing individuals with a fast-track to a second nationality and in some occasions, to rapidly acquiring more than one nationality by investment.

For international law purposes, the test of nationality applied by the I.C.J. in the Nottebohm case was that of "effective nationality". In Part 3 we will examine the

38 CÓRDOVA, Roberto. Report on Multiple Nationality. U.N. Doc. A/CN.4/83, para. 8 .

39 In March 2001 the United States Office of Personnel Management Investigations Service published a summary of the then existing nationalization policies of the world's states. Of the 188 States listed, 131 failed to recognize dual nationality. See: http:// www.multiplecitizenship.com/documents/IS-01.pdf. Acesso em: 28 nov. 2013.

40 AUDIT, Mathias. La coexistence de procédures contentieuses en matière d'investissements étrangers. Anuario Colombiano de Derecho Internacional (ACDI), v. 10, p. 333-370, 2017.

${ }^{41}$ KÄLIN, Christian H. Key Contours of Citizenship and Ius Doni: Ius Doni in International Law and EU Law. Brill Nijhoff, 2019. 17-58.

42 KRAKAT, Michael B. Genuine links beyond state and market control: the sale of citizenship by investment in international and supranational legal perspective. Bond Law Review, v. 30, p. 145, 2018. 
relevance of this test to Article 36 of the VCCR.

Until recently, the existence of dual nationalities was considered at best an inconvenience and at worst an evil. In any event it was to be avoided and discouraged. Spiro writes:

Instances of dual nationality are almost as old as the concept of nationality itself, and the phenomenon has been deplored for just as long. ${ }^{43}$

Allegiance was viewed as "perpetual" as embodied in the legal maxim "Nemo potest exuere patriam", meaning "no man may abjure his native country or the allegiance that he owes". ${ }^{44}$ The British had a more succinct way of capturing the idea, expressed in the saying: "Once an Englishman, always an Englishman". 45

The negative view of dual nationality persisted until well into the $20^{\text {th }}$ century. The 1930 Hague Convention on Certain Questions Relating to the Conflict of Nationality Laws (hereafter Hague Convention) includes in the opening averments:

BEING CONVINCED that it is in the general interest of the international community to secure that all its members should recognize that every person should have a nationality and should have only one nationality: ${ }^{46}$ (emphasis added)

The Hague Convention accepted the "Doctrine of Non-Responsibility of States for Claims of Dual Nationals" (the "doctrine of non-responsibility") which prohibited a State from affording diplomatic protection to a national against a State of which the individual is also a national. ${ }^{47}$

43 SPIRO, Peter. Dual nationality and the meaning of citizenship. Emory Law Journal, v. 46, p. 1411, 1997. supra note 12 at p 1417.

44 KETTNER, James. Subjects or Citizens? A Note on British Views Respecting the Legal Effects of American Independence. $\mathrm{Va}$. L. Rev, v. 62, n. 945, p. 947, 1976. at p. 947.

45 RUSSELL, Franklin. Dual nationality in practice-some bizarre results. Int'l Lanyer, v. 4, p. 756, 1969/1970. (hereinafter referred to as "RUSSELL"). One example of "indelible nationality" was that, despite the United States achieving independence in 1783, United States nationals were considered until 1870 to be British nationals and therefore subject to such measures as conscription into the British Royal Navy. See RUSSELL at p. 756.

461939 Hague Convention.

471939 Hague Convention. Art. 4. It is worth noting that the IranUnited States Claims Tribunal in its case A/18 questioned the continued efficacy of this prohibition and cautioned great care in its interpretation. See Iran - United Status Claims Tribunal: Decision in Case A/18 Concerning the Question of Jurisdiction Over Claims of Persons with Dual Nationality (1984), 23 Int'l Legal Materials 489 at page 497, and discussion in Part Three of this paper below.
The Convention also dealt with the issues of nationality of married women, children, adopted children and expatriation. Despite the foregoing, however, the Hague Convention had to recognize the right of states to determine who their own nationals were ${ }^{48}$, and that a person with two or more nationalities could be regarded as its national by either of the states involved. ${ }^{49}$

With regard to third states, however, it contained the following:

Within a third State, a person having more than one nationality shall be treated as if he had only one. Without prejudice to the application of its law in matters of personal status and of any conventions in force, a third State shall, of the nationalities which any such person possesses, recognize exclusively in its territory either the nationality in which he is habitually and principally resident, or the nationality of the country with which in the circumstances he appears to be in fact most closely connected. ${ }^{50}$

Thus, the Hague Convention, while seeking to achieve a goal of single nationalities for everyone, dealt with the dual nationalities problem by utilizing a form of the "effective nationality" test later adopted by the I.C.J. in the Nottebohm case.

In his 1954 report to the International Law Commission (ILC) entitled "Report on Multiple Nationality”, Special Rapporteur Roberto Córdova wrote:

The Special Rapporteur has already had the opportunity to state in his first report...that in the general interest of the international community every person should have a nationality, but only one nationality, and that every effort should be made to avoid double or multiple nationality. ${ }^{51}$

He goes on to explain that multiple nationality is "[...] a constant source of friction between States" and illustrates the problem through examples such as the possibility of multiple military service obligations and the complications that arise when States seek to grant diplomatic protection on behalf of dual nationals. ${ }^{53} \mathrm{Mr}$. Córdova's approach to resolving the multiple

\footnotetext{
481939 Hague Convention. Art. 1.

491939 Hague Convention. Art. 3.

501939 Hague Convention. Art. 5.

51 CÓRDOVA, Roberto. Report on Multiple Nationality. U.N. Doc. A/CN.4/83, para. 8. supra, note 15, para. 5.

52 CÓRDOVA, Roberto. Report on Multiple Nationality. U.N. Doc. A/CN.4/83, para. 8. para 6.

53 As noted, one specific difficulty that arises in regards to dual nationalities is the general rule that a State cannot exercise Diplomatic Protection on behalf of a national against a State of which the individual involved is also a national. This is referred to as the Doctrine
} 
nationalities problem involved deeming that individuals be deprived of all but their "effective nationality". ${ }^{54}$

Mr. Córdova then seeks to define "effective nationality".

To determine the effective nationality account will be taken of the following circumstances, either jointly or separately:

a) Residence in the territory of one of the States of which the individual concerned is a national;

b) In the case of residence in the territory of a state of which he is not a national, whether or not this State is a party, the previous and habitual residence in the territory of one of the States of which he is a national;

c) If the criteria mentioned in the above subparagraphs do not apply, any other circumstances showing a closer link de facto to one of the states of which he is a national, such as:

i) Military service;

ii) Exercise of civil and political rights or of political office;

iii) Language;

iv) His previous request of diplomatic protection from such State;

v) Ownership of immovable property..$^{55}$

Once again, "effective nationality" appears as the solution to the problem, in the international sphere, of dual nationality.

More recently, however, the issue of "dual nationality" has been seen less as an evil to be eliminated and more as a complication to be accommodated. Muchmore writes:

By the mid-1950's, however, international tribunals began to assert that, while an individual could validly have more than one nationality, only one of those nationalities could be dominant and effective for purposes of international law at any given time. ${ }^{56}$

In 1959, Zvonko R. Rode took the view that the rule of "dominant nationality" (as he referred to effective nationality) was, in fact, the older rule, and that the doctrine of non-responsibility of states, which had arisen

of Non-Responsibility of States for Claims of Dual Nationals. See Rode, supra note 14 at p. 141.

54 CÓRDOVA, Roberto. Report on Multiple Nationality. U.N. Doc. A/CN.4/83, para. 8. Basis 2 .

55 CÓRDOVA, Roberto. Report on Multiple Nationality. U.N. Doc. A/CN.4/83, para. 8. Basis 3 .

56 MUCHMORE, Adam I. Passports and nationality in international law. U.C. Davis J Int'l. L. and Pol'y, v. 301, p. 316, 2003/2004. at p. 316. more recently was destined to fall into disuse. ${ }^{57}$

Spiro writes:

Recent years have witnessed a marked softening in state attitudes towards dual nationality. States now appear more willing to accept the retention of nationality notwithstanding nationalization in a foreign state, at the same time as they have abandoned efforts to root out the underlying causes of dual nationality. ${ }^{58}$

While an examination of $\mathrm{t}$ he various modern attitudes towards dual nationality is beyond the scope of this paper, we note that there are those who go so far as to posit that a dual nationality is a human right. ${ }^{59}$ Times have changed, but there are some states which resist these new views, with harsh consequences for individuals.

\section{Diplomatic protection and its current issues under new challenges to the clasic rules on nationality in a globalized world}

Diplomatic Protection is distinct from the separate figure of Diplomatic Immunity and arises out of the essential sovereignty of the state itself. It is founded upon the historic right of states to act in protection of their citizens $^{60}$. Specifically, it is the right of a state to protect its nationals being victimized illegally by a foreign state in which they happen to be present ${ }^{61}$. The right is that of the state, not the victims, and arises out of the concept that an offence against a state's nationals is an offence against the state itself.

57 ZVONKO, R. Rode. Dual nationals and the doctrine of dominant nationality. A.J.I.L., v. 53, n. 1, p. 139, 1959. supra note 14 at p. 143.

58 SPIRO, Peter. Dual nationality and the meaning of citizenship. Emory Law Journal, v. 46, p. 1411, 1997. supra note 12 at p. 1453.

59 See MCGARVEY-ROSENDAHL, Patricia. A new approach to dual nationality. Hous. J. Int. L., v. 8, p. 305, 1985/1986. In which the author compares holders of earlier views of dual nationality with those with more modern views based on the reality of "[...] fin de siecle America in a shrinking globe [...]" at p 2 .

60 BROWNLIE, Ian. Principles of public international law. 6. ed. Oxford: Oxford University Press, 2003. at p. 391, where BROWNLIE characterizes this proposition of law as "trite".

${ }^{61}$ MACLEAN, R. J. Blaise. Fresh hay from old fields: the continuing usefulness of diplomatic protection. In: GALVIS, Ricardo Abello (ed.). Derecho internacional contemporáneo: lo público, lo privado, los derechos humanos: liberr amicorum en homenaje a Germán Cavelier. Rosario: Ed. Universidad del Rosario, 2006. p. 230-246. 
An important jurisprudential starting point for the concept is provided by the Permanent Court of International Justice (PCIJ) in the Mavrommatis Palestine Concessions $^{62}$ case:

\begin{abstract}
It is an elementary principle of international law that a State is entitled to protect its subjects when injured by acts contrary to international law by another State from whom they have been unable to obtain satisfaction through the ordinary channels. By taking up the case of one of its subjects and by resorting to diplomatic action or international judicial proceedings on his behalf, a State is in reality asserting its own right - its right to ensure, in the person of its subjects, respect for the rules of international law. ${ }^{63}$
\end{abstract}

Prof. John Dugard (appointed in 2000 by the ILC as Special Rapporteur on Diplomat Protection ${ }^{64}$ ) while acknowledging the existence of some underlying legal fictions, recognized the remaining importance of diplomatic protection as a remedy available to a State. ${ }^{65} \mathrm{He}$ identified a lack, at the international level, of the existence of substantive individual procedural rights, which led him to conclude that Diplomatic Protection as a remedy ought to be preserved:

Until the individual acquires comprehensive procedural rights under international law, it would be a setback for human rights to abandon diplomatic protection. ${ }^{66}$

Prof. Dugard seems to have been a goodforecaster: in March of 2019 the United Kingdom granted Diplomatic Protection to Nazanin Zaghari-Ratcliffe an Iranian-British national who has been imprisoned in Iran since April 2016 when she and her 22-month old dau-

\footnotetext{
${ }_{62}$ Mavrommatis Palestine Concessions, Greece v. United Kingdom, Objection to the Jurisdiction of the Court, Judgment, PCIJ Series A n. 2, ICGJ 236 (PCIJ 1924), 30 Aug. 1924. Permanent Court of International Justice.

63 Mavrommatis Palestine Concessions, Greece v. United Kingdom, Objection to the Jurisdiction of the Court, Judgment, PCIJ Series A n. 2, ICGJ 236 (PCIJ 1924), 30 Aug. 1924. Permanent Court of International Justice. Supra, n.1

64 DUGARD, John R. First Report on Diplomatic Protection. UN Doc. A/CN. 4/506, 7 Mar. 2000. (hereinafter "First Report") and published in The Report of the $52^{\text {nd }}$ Session of the International Law Commission (2000) U.N. Doc. A/55/10.

65 DUGARD, John R. First Report on Diplomatic Protection. UN Doc. A/CN. 4/506, 7 Mar. 2000. (hereinafter "First Report") and published in The Report of the $52^{\text {nd }}$ Session of the International Law Commission (2000) U.N. Doc. A/55/10. Para 21.

66 DUGARD, John R. First Report on Diplomatic Protection. UN Doc. A/CN. 4/506, 7 Mar. 2000. (hereinafter "First Report") and published in The Report of the $52^{\text {nd }}$ Session of the International Law Commission (2000) U.N. Doc. A/55/10. Para 29.
}

ghter were taken into custody. ${ }^{67}$ Ms. Zaghari-Ratcliffe received a five-year sentence for "spying". Her now four-year-old daughter has been unable to return to the UK to join her father. Due to lack of progress in negotiating her release, and allegations of mistreatment in prison by Iranian authorities, the UK has “...raise(d) her case from a consular matter to the level of a dispute between the two states." ${ }^{\prime 6}$ The requirements for a successful claim of Diplomatic Protection give rise to some of the issues of nationality, yet it is a matter of interest that the remedy remains alive as recommended by Dugard. ${ }^{69}$

As noted, when Diplomatic Protection is invoked it is a right of the State that is being enforced. Victims have no in personam right to have diplomatic protection enforced on their behalf. ${ }^{70}$ Thus, it falls entirely within the discretion of the State and its procedures to determine whether, it is appropriate to seek satisfaction arising from a wrong committed against its national. From the state's perspective, of course, this is the preferable position, as it allows the exercise its own discretion. Consequently, international law recognizes no human right to diplomatic protection. ${ }^{71}$

International law has established the following parameters in order to invoke a claim for diplomatic protection:

67 FOREIGN Office grants Zaghari-Ratcliffe diplomatic protection. The Guardian, Mar. 2019. Disponível em: https://www.theguardian.com/news/2019/mar/07/foreign-office-grants-nazaninzaghari-radcliffe-diplomatic-protection. Disponível em: 3 abr. 2019. 68 FOREIGN Office grants Zaghari-Ratcliffe diplomatic protection. The Guardian, Mar. 2019. Disponível em: https://www.theguardian.com/news/2019/mar/07/foreign-office-grants-nazaninzaghari-radcliffe-diplomatic-protection. Disponível em: 3 abr. 2019. ${ }^{69}$ Of note, the authors herein have posited the availability of diplomatic protection as a remedy available in regard to the mistreatment by Venezuelans of Colombians resident in that country. See: MACLEAN, Robert Joseph-Blaise; AREVALO, Walter. The expulsion of resident colombian nationals during the Colombia-Venezuela border dispute: an under the radar: case for diplomatic protection of human rights?. Vniversitas, v. 68, n. 138, 2019.

70 See, e.g. DUGARD, John R. First Report on Diplomatic Protection. UN Doc. A/CN. 4/506, 7 Mar. 2000. (hereinafter "First Report") and published in The Report of the $52^{\text {nd }}$ Session of the International Law Commission (2000) U.N. Doc. A/55/10. supra, n.3, para 75 as to the traditional position, Barcelona Traction Light and Power Company Ltd, 1970 ICJ Reports 1 at p 44, and WARBRICK, Colin. Diplomatic representations and diplomatic protection. ICLQ, v. 51, p. 723,2000 . at p. 1008, in reference to the British Rules.

71 WARBRICK, Colin. Diplomatic representations and diplomatic protection. ICLQ, v. 51, p. 723, 2000. (hereinafter "Diplomatic Representations") at p. 731. This does not, of course, preclude the right of States to grant this right to their citizens under domestic law. 
(a) the commission of an "international wrong", that is, act contrary to international law, ${ }^{72}$

(b) the international wrong must be attributable to a State,

(c) the international wrong must have been committed against a national of another State ${ }^{73}$,

(d) local remedies must have been exhausted. This means that the national must have sought and been unable to obtain relief from the offending State through "ordinary means" (generally referred to as the exhaustion of local remedies requirement) ${ }^{74}$.

(e) the continuous nationality requirement must be complied with, which means that victim must have been a national of the complaining State both at the time the wrong was committed and when the complaint was lodged ${ }^{75}$,and

(f) the victim cannot be a national of both the offending State and the complaining State, that is, no dual nationality as regards the two involved states. $^{76}$

This paper's focus on "nationality" means examination of the alleged "clean hands" requirement falls outside its scope.

Nationality is fundamental to Diplomatic Protection (as it is to Consular Assistance). If the victim is a dual national and one of those nationalities is of the state against which Diplomatic Protection is claimed, then a classic view would be that the claim may not be sustained at international law. Whether this classic formulation remains intact will be discussed more specifically in Part Four below.

The nationality issue arose in relation to the Iran United States Claims Tribunal. The Tribunal was res-

\footnotetext{
72 The issue of what is an "international wrong" is a question of the Primary Rules, that is to say, what acts justify the invocation of diplomatic protection and when (and on what basis) is state responsibility engaged; this will be discussed below.

73 See DUGARD, John R. First Report on Diplomatic Protection. UN Doc. A/CN. 4/506, 7 Mar. 2000. supra, n. 3, para. 36. "[...] it is a widely accepted rule of customary international law that States have the right to protect their nationals abroad."

74 Interhandel Case, 1959 ICJ Reports 27; Elettronica Sicula S.p.N. Case (ELSI) 1989 ICJ Reports 42. This rule is the subject matter of the Special Rapporteur's Second Report on Diplomatic Protection UN. Doc. A/CN/.4/514 (hereinafter "Second Report").

75 See LEIGH, Guy I. F. Nationality and diplomatic protection. Int'l and Comp. L. Q, v. 20, n. 453, p. 456, 1971. at p. 456. cf. DUCHESNE, Matthew S. The continuous-nationality-of-claims principle: its historical development and current relevance to investor-state investment disputes. Geo. Wash. Int'l L. Rev, v. 36, p. 783, 2004. in which the author disputes whether continuous nationality is, in fact, a rule. 76 BROWNLIE, Ian. Principles of public international law. 6. ed. Oxford: Oxford University Press, 2003. supra, n. 11, p. 404-405.
}

ponsible for adjudicating claims by United States nationals in regards to the lump - sum settlement paid by Iran, pursuant to the Algiers Declaration, in settlement of claims arising from the Iranian Revolution. In adjudicating the claims, the tribunal was to apply "[...] applicable principles of international law, justice and equity", among other considerations. ${ }^{77}$

An issue that arose with some frequency before the tribunals involved claims by dual United States - Iranian nationals. Iran took the position that individuals, who were Iranian citizens under Iranian law, could not bring claims against Iran before the tribunal, even if they were also citizens of the United States. ${ }^{78}$ Iran's position was summarized as follows:

The International law pertaining to the exercise of diplomatic protection clearly prohibits claims by persons who possess the nationality of both the claimant and respondent states. ${ }^{79}$

The United States took the position that as the Algiers Declaration defined "nationals" as "citizens", all United States nationals, including dual nationals, could make claims before the tribunal. ${ }^{80}$

The tribunal accepted neither position.

The tribunal embarked on an international law analysis of the issue of dual nationals and reached a number of relevant conclusions.

1. The Algiers declaration is a treaty and is to be interpreted in accordance with the Vienna Convention on the Law of Treaties (VCLT) ${ }^{81}$

2. The terms of the Algiers Declaration must be given their ordinary meaning in terms of their context and in the light of its aims and purposes.

LILLICH, Richard B.; BEDERMAN, David J. Jurisprudence of the foreign claims settlement commission: Iran claims. AJIL, v. 91, p. 436, 1997.

78 IRAN-United States claims tribunal: decision in Case A/18 concerning the question of jurisdiction over claims of persons with dual nationality. Int'l Legal Materials, v. 23, p. 489, 1984. at p. 491.

79 IRAN-United States claims tribunal: decision in Case A/18 concerning the question of jurisdiction over claims of persons with dual nationality. Int'l Legal Materials, v. 23, p. 489, 1984. at p. 493.

80 IRAN-United States claims tribunal: decision in Case A/18 concerning the question of jurisdiction over claims of persons with dual nationality. Int'l Legal Materials, v. 23, p. 489, 1984. at p. 496.

81 IRAN-United States claims tribunal: decision in Case A/18 concerning the question of jurisdiction over claims of persons with dual nationality. Int'l Legal Materials, v. 23, p. 489, 1984. at p. 496. 
3. In so doing, Article 31 (c) of the VCLT directs tribunals to take into account any "relevant rules of international law applicable to the relations between the parties". ${ }^{82}$

4. It recognized that the 1930 Hague Convention upheld the principle, in Art. 4, that diplomatic protection could not be afforded in cases of dual nationality where the individual was a national of both state parties. The tribunal cautioned, however, that Art. 4 must be interpreted very cautiously because:

Not only is it more than 50 years old and found in a treaty to which only 20 States are parties, but great changes have occurred since then in the concept of diplomatic protection, which concept has been expanded.

1. Even if the "non-responsibility" doctrine still applies to diplomatic protection that is a matter between states. The tribunal distinguished itself from such issues by observing that it dealt with rights of individuals. $^{83}$

The tribunal, following an analysis of recent jurisprudence and legal literature concluded "[...] that the 'actually dominant theory' $[. .$.$] is, at least before inter-$ national tribunals, the effective nationality theory." ${ }^{\prime 4}$ The tribunal said:

This trend toward modification of the Hague Convention rule of non-responsibility by search for the dominant and effective nationality is scarcely surprising as it is consistent with the contemporaneous development of international law to accord legal protection to individuals, even against the State of which they are nationals. ${ }^{85}$

The tribunal then concluded that:

Thus, the relevant rule of international law which the Tribunal may take into account for purposes of interpretation, as directed by Article 31, paragraph 3

\footnotetext{
82 IRAN-United States claims tribunal: decision in Case A/18 concerning the question of jurisdiction over claims of persons with dual nationality. Int'l Legal Materials, v. 23, p. 489, 1984. at p. 497.

83 IRAN-United States claims tribunal: decision in Case A/18 concerning the question of jurisdiction over claims of persons with dual nationality. Int'l Legal Materials, v. 23, p. 489, 1984. at p. 498.

${ }^{84}$ IRAN-United States claims tribunal: decision in Case A/18 concerning the question of jurisdiction over claims of persons with dual nationality. Int'l Legal Materials, v. 23, p. 489, 1984. at p. 500.

85 IRAN-United States claims tribunal: decision in Case A/18 concerning the question of jurisdiction over claims of persons with dual nationality. Int'l Legal Materials, v. 23, p. 489, 1984. at p. 501.
}

(c), of the Vienna Convention is the rule that flows from the dictum of Nottebohm, the rule of real and effective nationality, and the search for "stronger factual ties between the person concerned and one of the States whose nationality is involved". ${ }^{86}$

Accordingly, the tribunal held that it had jurisdiction over claims against Iran by dual United States-Iranian nationals whose effective nationality during the relevant period was that of the United States. ${ }^{87}$

The significance of this decision is the assertion of the existence of an objective test of nationality for international law purposes. Feeley writes:

In adopting the Nottebohm doctrine, the tribunal upheld an objective test of nationality while considering the internal laws of the United States and Iran. The tribunal acknowledged the validity of both parties' domestic laws but simultaneously refused to rely exclusively on such internal rules when determining the nationality of the claimant before the tribunal. The tribunal thereby advanced the individual rights of the claimant vis-à-vis the state without expressly infringing state sovereignty ${ }^{88}$

As international tribunals have been consistent in their application of the effective nationality test, ${ }^{89}$ the question arises whether this may be applied to dual nationality situations under the VCCR will be discussed below.

Muchmore points out that it would be "[...] inconsistent with international nationality law to apply the law of binding state action to the country of non-dominant nationality if the internal laws of that country do not recognize dual nationality." ${ }^{00}$ The issue, however, is not the application of the internal law to individuals such as Mrs. Kazemi, and Mr. Celil and others. Even if the municipal courts have jurisdiction over them, for domestic purposes, this does not change the international position which would regard their nationality for internatio-

86 IRAN-United States claims tribunal: decision in Case A/18 concerning the question of jurisdiction over claims of persons with dual nationality. Int'l Legal Materials, v. 23, p. 489, 1984.

87 IRAN-United States claims tribunal: decision in Case A/18 concerning the question of jurisdiction over claims of persons with dual nationality. Int'l Legal Materials, v. 23, p. 489, 1984.

88 SCOTT, Michael. Iran-United States Claims Tribunal: decision in Case A/18 concerning the question of jurisdiction over claims of persons with dual nationality. Harv. Int'l L.J., v. 26, p. 208, 1985. at p. 216.

89 MUCHMORE, Adam I. Passports and nationality in international law. U.C. Davis J Int'l. L. and Pol'y, v. 301, p. 316, 2003/2004. supra note 31 at p. 314.

90 MUCHMORE, Adam I. Passports and nationality in international law. U.C. Davis J Int'l. L. and Pol'y, v. 301, p. 316, 2003/2004. 
nal law purposes, as being the dominant and effective nationality.

\section{Consular assistance under the new challenges on the concept of nationality}

Normally, individuals who find themselves outside their home countries may avail themselves of consular assistance. Consular assistance is provided for under the Vienna Convention on Consular Relations (VCCR) ${ }^{91}$ and includes, among other things, the right of states, through consular officials to extend certain services to any of their nationals in need.

Among the services contemplated by the VCCR are those relating to assistance to be provided to nationals of the "sending State" who may have been arrested or find themselves in legal difficulty with officials of the "receiving State".

Article 36 of the Vienna Convention on Consular Relations $1963^{92}$ includes the following provisions:

\section{Article 36}

1) With a view to facilitating the exercise of consular functions relating to nationals of the sending State:

a) Consular officials shall be free to communicate with nationals of the sending State and to have access to them $[\ldots]$

b) $[\ldots]$

c) Consular officials shall have the right to visit a national of the sending State who is in prison, custody or detention, to converse and correspond with him and to arrange for his legal representation. They shall also have the right to visit any national of the sending State who is in prison, custody or detention in their district in pursuance of a judgment $[\ldots]$

2) The rights referred to in paragraph 1 of this article shall be exercised in conformity with the laws and regulations of the receiving State, subject to the proviso, however, that the said laws and regulations must enable full effect to be given to the purposes for which the rights accorded under this article are intended.

\footnotetext{
91 UNITED NATIONS. Treaty Series, v. 596, p. 261, hereinafter referred to as VCCR.

92 UNITED NATIONS. Treaty Series, v. 596, p. 261, hereinafter referred to as VCCR.
}

The Article provides very limited, but clear and unambiguous, rights. Yet situations have arisen in which parties to the convention are refusing to grant even limited Article 36 rights to consular representatives seeking to monitor judicial proceedings of their nationals abroad. The situations tend to arise in cases in which an accused dual national faces legal difficulty in the state of his birth nationality, and the state of his nationalization seeks to provide him/her with consular assistance. This problem also exists in the context of Diplomatic Protection when a state seeks to "protect" one of its nationals against a state of which the victim is also a national.

This problem arises because there are states that do not recognize adopted nationalities of persons they consider their own nationals; indeed, as noted earlier a majority of states do not recognize dual nationality. Yet we live in a time of increasing globalization and migration of people. It is not difficult to imagine that, as more people adopt dual nationalities, problems arising from non-recognition of second nationalities may become more frequent.

Regarding the cases noted in the Introduction, both Iran and China are parties to the VCCR ${ }^{93}$. The VCCR is considered a codification of customary international law; further, those matters not expressly addressed by the VCCR continue to be governed by customary international law. ${ }^{94}$ Iran, but not China, is also a party to the Optional Protocol to the VCCR Concerning the Compulsory Settlement of Disputes, having acceded on 5 June $1975 .{ }^{95}$

As stated, a state's application of its own definition of nationality may be inadequate for international law purposes. Accordingly, the failure of Iran and China to recognize, domestically, the adopted nationalities of Mrs. Kazemi and Mr. Celil may have violated their international law obligations. ${ }^{96}$ Further, and specifically as to

\footnotetext{
93 Iran ratified the VCCR on 5 June 2975; China acceded to the VCCR on 2 July 1979. See: Multilateral treaties Deposited With the Secretary-General. Disponível em: http://treaties.un.org/Pages/ ParticipationStatus.aspx. Acesso em: 26 nov. 2013.

94 VCCR supra, note 2, opening averments.

95 Multilateral treaties Deposited With the Secretary-General, supra note 54 at http://untreaty.un.org/ilc/texts/getter.asp. Canada is not a party and the United States has withdrawn from it.

96 The problem does not arise when the dual national is detained in a country in which he/she is not a national. The recent case of Luis Carlos Cossio is an example. Cossio was detained by Venezuela in April 2010 in relation to suspicion of espionage. Cossio is a dual
} 
China, though they have acknowledged Mr. Kovrig and Mr. Spavor as Canadian nationals, the limitations placed upon them in the exercise of their consular assistance raises questions as to whether China has violated its VCCR obligations. ${ }^{97}$

Based upon the discussion above as to the evolving international treatment of "nationality" it is argued here that the domestic position regarding nationality ought to have no bearing on the issue as to whether dual nationals are entitled to receive consular assistance. The VCCR is an international convention, embodying customary international law. If Nottebohm means anything, it stands for the proposition that international law is not bound by domestic rules as to nationality. Does the dominant nationality test apply to the issue of nationality under the VCCR? Arguably yes, based upon six considerations:

1. The trend of international tribunals to apply the dominant and effective nationality test.

2. Even if the majority of the cases involving the issue have been in the context of diplomatic protection, the Iran - United States Claims Tribunal decision made it clear that the "doctrine of nonresponsibility" has more than likely been overtaken by time,

3. Even if the "doctrine of non-responsibility" has survived, it seems to be on its last legs. The Iran - United States Claims Tribunal took the view that if it survives, it is in the area of diplomatic protection. When the claim of an individual against a State is at issue, the "dominant and effective nationality" test should be applied.

4. In this context, the issue arises whether the right to consular assistance is a right of a State or the right of an individual. As noted above, the definition of "consular functions" is defined to include protecting the interests of "[...] the sending state and

Colombia-Canadian national and, accordingly, Canada has sought to provide consular assistance on his behalf. To date there is no indication that Venezuela has denied access. See: El Universal, 9 Apr. 2010. online edition. Disponível em: http://calidaddevida.eluniversal.com/2010/04/09/pol_ava_canada-solicita-visi_09A3718813. shtml. Acesso em: 27 nov. 2013.

97 And, of course, the Diplomatic Immunity issue as regards Mr. Kovrig is yet another matter in which questions of Chinese compliance with international legal obligations have arisen. of its nationals $[\ldots]^{\prime \prime 98}$ (emphasis added). This inclusive language would seem to mean that not only the state but the individual nationals have interests. In such circumstances, particularly if a Section 31 and 32 of the Vienna Convention on the Law of Treaties analysis is applied (as it was by the tribunal), any ambiguity in the language would have to be resolved in favour of recognizing the "dominant and effective nationality test".

5. The same analysis ought to apply in interpreting the Canada - China Consular agreement which includes as a consular functions the "protecting and securing of the rights and interests of the sending state and its nationals". ${ }^{9}$

6. As noted, international law has been expanding its recognition of the rights of individuals' vis-à-vis states. Indeed, this was one reason that the Tribunal gave for deciding upon the dominant and effective nationality test. Other scholars, as noted, have been propounding the view that the right to a dual nationality is a right.

Even if there is no right to have a dual nationality, however, it appears clear that is open to international law to interpret "national" for the purpose of the VCCR as the dominant and effective nationality of the individual in question. That, in the end, becomes a question of fact. The tribunal would have to examine the life and situation of the individual in question to assess with which state such an individual had the closest links. Tests are suggested in Nottebohm and in a number of the individual cases before the Iran-United States Claims tribunal, but that is the subject for another paper.

\section{Analysis and context}

\subsection{Context and examples}

It would be inaccurate to assert that the issue of dual or multiple nationalities is a new problem engendered by globalization and increasing mobility of peoples. It

\footnotetext{
98 Supra, note 6.

99 Supra, note 45 Art. 2 (a).
} 
is fair to say, however, that the modern approach to the issue of nationality comes as a reaction to modern attitudes towards personal mobility.

In today's world of mobile populations, instantaneous communication, globalization in terms of trade and commerce and the evolution of transnational methods of dispute resolution not only for states, but for individuals, it is becoming common to refer to the "Global Village". But while it may be pleasant to envision ourselves as "citizens of the world" "we cannot escape the fact that concepts of nationality which evolved in the $18^{\text {th }}, 19^{\text {th }}$ and $20^{\text {th }}$ centuries still provide the basis upon an individual's place in the world is established, and these concepts may, from time to time, create unwelcome surprises.

Though there may be no "right" per se to have a dual nationality it appears clear from the foregoing that is open to international law to interpret "national" for the purpose of Diplomatic Protection and the VCCR as the dominant and effective nationality of the individual in question.

The Zaghari-Ratcliffe case noted above illustrates this point. Ms. Zaghari Ratcliffe is a dual Iranian-UK national. The UK has taken the view that the denial of necessary medical care and medicine as well as the denial of access to her own doctor is the "international wrong" supporting the claim for Diplomatic Protection. ${ }^{101}$ But Iran does not recognize dual nationality. Thus, Iran does not recognize her UK nationality. Iran says she has been treated as any other Iranian national and that the UK claim for Diplomatic Protection violates international law. ${ }^{102}$

While the Iranian position reflects the classical view of the applicability of Diplomatic protection, the evolution towards an effective or dominant nationality test for international law purposes could open the door for a different result in this case. It is the position of the authors that this would be a progressive development of international law that ought to be encouraged. Specifically, as is clear from cases such as Nottebohm, international law is clear that, for municipal purposes,

\footnotetext{
100 See for example a discussion on the possibility of extending nationality beyond the nation state in BOSNIAL, Linda. Citizenship denationalized. Ind. J. Global Leg. St., v. 7, p. 447, 1999/2000.

101 https://www.theguardian.com/news/2019/mar/07/foreignoffice-grants-nazanin-zaghari-radcliffe-diplomatic-protection.

102 https://www.france24.com/en/20190312-iran-says-uk-diplomatic-protection-jailed-mother-wont-make-things-easier.
}

states may determine nationality. They decide who to recognize, and who not to recognize, as nationals for their own sovereign purposes. But on the international plane, and for purposes of international law, there is no obligation to accept municipal definitions of nationality. Indeed, international law has been clear that it will determine for itself what nationality is for purposes of international law, and that the "effective nationality" standard is the measure it will apply. This would entail no infringement on any state's sovereign right to determine, for its own purposes, who is or is not a national of that state. It would only prevent its imposition of that definition upon the international plane, an approach clearly applied in the famous Nottebohm case. This view is further enhanced by the views cited above in the Iran - United Status Claims Tribunal which acknowledged the expansion of the remedy of Diplomatic Protection in the years since the 1930 Hague Convention came into being. ${ }^{103}$

The following cases illustrate the need for the suggested evolution in recognition of nationality to be adopted:

\subsubsection{Zahra Kazemi}

Ms. Kazemi was an Iranian-born naturalized Canadian citizen who, at the age of 54 years, died while in custody in Iran. She was a photojournalist and had traveled to Iran in Spring 2003 to cover student riots happening at the time. She was arrested by Iranian authorities on 23 June 2003 for taking photos outside a prison in Teheran. She died on 11 July 2003. ${ }^{104}$ Iranian Vice President Mohammad Ali Abhati acknowledged on 16 July 2003 that, despite earlier representations by the Iranian authorities that she had suffered a stroke, she had in fact died from being beaten. ${ }^{105}$

After her death, Canadian authorities, in support of her son's request, sought unsuccessfully the return of her body to Canada for burial and so that a proper forensic investigation could be conducted. The Special

\footnotetext{
103 Supra, note 59.

104 For a full description of the facts of Ms. Karemi's death please refer to the decision of the Quebec Court of Appeal in Islamic Republic of Iran v. Hashemi 12 August 20122012 QCCA 1449, p 3-5. 105 LIGABO, Ambeyi. Special Rapporteur. U.N. High Commission on Human Rights on the Right to Freedom of Opinion and Expression. Report on Mission to the Islamic Republic of Iran. 12 Jan. 2004. U.N. Doc. E/CN.4/62/Add 2, para. 74.
} 
Rapporteur for Freedom of Expression appointed by the United Nations Commission of Human Rights, Ambeyi Ligabo, traveled to Iran in 2003 to consult with Iranian authorities about a number of complaints that had been received about the situation there. In his report to the Commission he wrote:

[...] the Special Rapporteur appeals to the authorities to allow Mrs. Kazemi to be buried in Canada, in accordance with the express wish of Mrs. Kazemi's son, Stephen Hachemi, and her mother, Ezzat Kazemi. ${ }^{106}$

Iran denied these requests. Throughout, Iran did not to recognize Ms. Kazemi’s Canadian nationality and refused to allow Canadian involvement in any investigations, or judicial proceedings. Family members of Ms Kazemi living in the Canadian province of Quebec sought to sue the Iranian government for damages caused by her torture-death. The case was begun in the Quebec Courts, but without success for the Plaintiffs. The final appeal to the Supreme Court of Canada was also rejected. The Court, though clearly sympathetic to the family, determined that the State Immunity Act107 shielded Iran from liability. Thus state sovereignty ultimately applied to shield the Iranian state from the consequences of its acts. ${ }^{108}$

Iranian law does not recognize dual nationality. The United States Office of Personnel Management Investigations Service reports that involuntary denationalization is virtually impossible. Even voluntary denationalization, which requires the rarely granted consent of the Council of Ministers, is almost completely unavailable. ${ }^{109}$ Thus if a person is born Iranian, or even if their father was born Iranian, he or she may unexpectedly find themselves regarded by Iran as falling under Iranian legal jurisdiction. In such circumstances, the effective nationality definition should apply.

\subsubsection{Huseyincan Celil}

Mr. Celil is another naturalized Canadian citizen, but born with Chinese nationality. Ethnically, he is a Uighur

\footnotetext{
106 LIGABO, Ambeyi. Special Rapporteur. U.N. High Commission on Human Rights on the Right to Freedom of Opinion and Expression. Report on Mission to the Islamic Republic of Iran. 12 Jan. 2004. U.N. Doc. E/CN.4/62/Add 2, para. 74. at para 80.

107 R.S.C., 1985 , c. S-18.

108 The result today could well be different since now Iran is one of only two states whose immunity has been lifted for the purposes of the Justice for Victims of Terrorism Act.

109 Supra note 15 at p. 97.
}

a largely Muslim minority group. He was born and raised in China but came to Canada with his wife in 2000 as a refugee. Sometime after that he received his Canadian citizenship. ${ }^{110}$

Some Chinese Uighurs have been agitating within China for greater autonomy. It appears that Mr. Celil was active in this movement. Chinese authorities have accused these groups of terrorism, with the result that Mr. Celil was sought for prosecution.

According to reports, Mr. Celil was in Uzbekistan in March 2006 visiting relatives of his wife. He was arrested by Uzbek authorities, and Canadian officials were made aware of the arrest. Canada sought his return to Canada, but Uzbekistan, instead, extradited him to China where he was put on trial for terrorist related charges.

Chinese nationality law does not recognize dual nationality ${ }^{111}$; further, as regards Chinese nationals adopting another nationality, Article 9 of the Nationality Law of the People's Republic of China provides that:

Any Chinese national who has settled abroad and who has been naturalized as a foreign national or has acquired foreign nationality of his own free will shall automatically lose Chinese nationality. ${ }^{112}$

Canadian diplomats in China have repeatedly attempted to meet with Mr. Celil, to attend his judicial hearings and provide other forms of consular assistance. Despite the foregoing provisions, however, all attempts to provide consular assistance have been denied by Chinese authorities on the basis that they do not recognize his Canadian citizenship. Thus, from the Chinese viewpoint, the case is not subject to consular agreements. The position they take is that, as a dual citizen, he is subject to Chinese laws. ${ }^{113}$

Mr. Celil was convicted in April 2007 of "splitism" and terrorist related charges. Throughout the procee-

110 http://us.cnn.com/2007/WORLD/americas/07/10/canada. detainee.ap/index.html. (DEAD LINK).

111 Nationality Law of the People's Republic of China. Disponível em: http://www.china.org.cn/english/LivinginChina/184710.htm. Acesso em: 28 nov. 2013. Article 3.

112 Nationality Law of the People's Republic of China. Disponível em: http://www.china.org.cn/english/LivinginChina/184710.htm. Acesso em: 28 nov. 2013. Article 9.

113 FAMILY seeks whereabouts of jailed chinese-canadian activist. CBC Canada, 28 Mar. 2008. Disponível em: http://www.cbc.ca/ news/canada/family-seeks-whereabouts-of-jailed-chinese-canadian-activist-1.762192. Acesso em: 26 nov. 2013. The article points out that, generally, Chinese automatically lose their citizenship upon taking another nationality. 
ding no Canadian diplomat was permitted to attend. Mr. Celil's whereabouts are a mystery. He has been moved to a new prison, and Chinese officials refuse to disclose where he is. According to Mr. Celil's Canadian lawyer, Chris MacLeod, the request for information about his new locations was denied on the basis that Mr. Celil was a Chinese citizen and no one has standing to make enquiries. ${ }^{114}$

Amnesty International (Canada) wrote a letter to then Canadian Prime Minister Stephen Harper on the matter requesting further Canadian government efforts on Mr. Celil's behalf. ${ }^{115}$ In addition, the United States House of Representatives passed a "sense of the House "resolution which said that China "[...] should immediately release Canadian citizen Huseyin Celil (sic) and allow him to rejoin his family in Canada". ${ }^{116}$

China's non-recognition of Mr. Celil's Canadian nationality is disturbing for a number of reasons. First, he was not in China at the time of his apprehension; he was in Uzbekistan; Uzbek authorities extradited him to China rather than returning him to Canada as requested by the Canadian government. Secondly, in addition to the VCCR, to which both Canada and China are parties, there is a Consular Agreement between Canada and China relating to the provision of consular services to nationals of each country. ${ }^{117}$ There is no mention within that document that China does not recognize dual nationality nor does it exclude dual nationals from the definition of those entitles to consular services. Thus, China's treatment of Mr. Celil, or at least its disregard of Canada's desire to offer consular services, is somewhat more surprising than the Iranian position. ${ }^{118}$ Nevertheless, China's position was stated by Foreign

114 "Canada angry at Uighur sentence" TheSpec.com - Local China remains silent on Burlington man's welfare. BBC News, 20 Apr. 2007. Disponível em: http://news.bbc.co.uk/2/hi/asia-pacific/6574517.stm. Acesso em: 26 nov. 2013.

115 Amnesty International letter to P.M. Stephen Harper dated 28 Mar. 2008. copy on file with the author.

116 H.Res 497 Passed. 17 Sept. 2007. Disponível em: https://www. govtrack.us/congress/bills/110/hres497/text. Acesso em: 26 nov. 2013.

117 CONSULAR Agreement Between the Government of Canada and the Government of the People's Republic of China. Disponível em: http://travel.gc.ca/about/assistance/consular/framework/ china. Acesso em: 26 nov. 2013.

118 It is to be noted in this regard that Canada's relations with Iran have been tense since 1979 when, during the occupation of the United States Embassy in Teheran by Iranian students, Canadian diplomats succeeded in helping a number of their United States colleagues escape from Iran disguised as Canadians.
Ministry spokesman Liu Jianchao: "The case of $\mathrm{Hu}-$ seyincan Celil is an internal affair, and Canada has no right to interfere." 119

\subsubsection{Haleh Esfandiari}

Another example is that of Haleh Esfandiari who in 2006 was an Iranian-American, Director of the Middle East Programme of the Woodrow Wilson International Institute for Scholars ${ }^{120}$ which was described in the Washington Post as one of Washington's "most prominent" foreign policy think tanks. ${ }^{121}$ Her sudden arrest in Teheran while returning from a visit to her mother led to her being in Iranian custody until September 2008 on suspicion of "security crimes". ${ }^{122}$ She was originally kept under house arrest but on 9 May 2007 she was formally arrested and sent to Evin Prison (where Zahra Karemi received her fatal beating) on suspicion of "security crimes". In a statement released after her return to the United States, she indicated that although her jailers were polite, she was kept in solitary confinement for 105 days, and denied visitors or contact with legal counsel. ${ }^{123}$

\subsubsection{Others}

There are approximately 200 Canadian citizens and other westerners under arrest or detention in China including:

- Sun Qian a Chinese-born Canadian arrested in Beijing in 2017. ${ }^{124}$

119 CANADA angry at Uighur sentence. BBC.com, 20 Apr. 2007. Disponível em: http://news.bbc.co.uk/2/hi/asia-pacific/6574517. stm. Acesso em: 10 abr. 2019.

120 See: http://www.wilsoncenter.org/article/statement-the-arrest-tehran-haleh-esfandiari-director-the-woodrow-wilson-centersmiddle-east. Acesso em: 26 nov. 2013.

121 See: TEHRAN jails iranian american scholar after long house arrest. Washington Post, 9 May 2007. Disponível em: http://www. washingtonpost.com/wp-dyn/content/article/2007/05/08/ AR2007050801276.html?nav=hcmodule. Acesso em: 26 nov. 2013.

122 AFTER months of uncertainty and imprisonment Dr. Haleh Esfandiari returns home. Wilson Centre. Disponível em: http://www. wilsoncenter.org/article/after-months-uncertainty-and-imprisonment-dr-haleh-esfandiari-returns-home-0. Acesso em: 26 nov. 2013. 123 http://www.wilsoncenter.org/index.cfm?topic_ id $=1426 \&$ fuseaction $=$ topics.item\&news_id $=285716$

124 GRAUER, Perrin; CHIU, Joanna. The 'forgotten' Canadians detained in China. The Toronto Star, 20 Dec. 2018. Disponível em: https://www.thestar.com/vancouver/2018/12/20/the-forgottencanadians-detained-in-china.html. 
- John Chang, a Taiwan-born winery owner from Richmond BC being held on taxrelated charges. ${ }^{125}$

- Xian Jianhua, a Chinese-born Canadian billionaire reportedly taken from a Hong Kong hotel by wheelchair and removed to China. ${ }^{126}$

- Yang Henjun, an Australian novelist and former diplomat who was taken into custody but whose whereabouts are unknown. ${ }^{127}$

These are just China, and do not include Iranian held prisoners. The common element in all of these cases, and other similar ones ${ }^{128}$, is that the state of birth has not recognized the adopted nationality of the subject. As noted above China, on paper, has a mechanism for the recognition of dual nationality and it is unclear why, in the case of Mr. Celil, it did not recognize his adopted Canadian nationality. More troubling, of course, is the fact that Mr. Celil was not in China at the time of his apprehension. He was in Uzbekistan and there is a valid question as to why he was extradited to China and not to Canada. Thus, each of them had adopted a new nationality or nationalities, each had ended up (one way or another) in the state of their birth, each had run into legal difficulties with the authorities and in each case the state of new nationality was unable to assist their citizens as a result of the non-recognition by the birth state of the new nationality.

Nonetheless, it is abundantly clear that, despite the clear provisions of the VCCR, the application of these provisions may place certain people's liberty in doubt.

125 GRAUER, Perrin; CHIU, Joanna. The 'forgotten' Canadians detained in China. The Toronto Star, 20 Dec. 2018. Disponível em: https://www.thestar.com/vancouver/2018/12/20/the-forgottencanadians-detained-in-china.html.

126 GRAUER, Perrin; CHIU, Joanna. The 'forgotten' Canadians detained in China. The Toronto Star, 20 Dec. 2018. Disponível em: https://www.thestar.com/vancouver/2018/12/20/the-forgottencanadians-detained-in-china.html.

127 CANADIANS and Chinese justice: a who's who of the political feud so far. The Globe and Mail, Toronto, 15 Jan. 2019. Disponível em: https://www.theglobeandmail.com/world/article-canadiansdetained-china-huawei-explainer/.

128 According to the Toronto Star there are at least 200 Canadians held in Chinese custody. See: MACCHARLES, Tonda. 'Hundreds' of Canadians held by China raises the stakes for Trudeau's government. The Toronto Star, 20 Dec. 2019. Disponível em: https://www. thestar.com/politics/federal/2018/12/20/hundreds-of-canadiansheld-by-china-raise-stakes-for-trudeau-government.html.
The question to be asked is whether International Law possesses a means for the resolution of this ambiguity.

\subsection{Analysis: the continuing impact of effective nationality in international dispute settlement}

As parties to the $\mathrm{VCCR}^{129}$, which is also considered a codification of customary international law, both China and Iran are bound to allow consular assistance to nationals of other states. Indeed, those matters not expressly addressed by the VCCR continue to be governed by customary international law. ${ }^{130}$ Iran, though not China, is also a party to the Optional Protocol to the VCCR Concerning the Compulsory Settlement of Disputes, having acceded on 5 June $1975 .{ }^{131}$ Diplomatic Protection is also a part of the body of international customary law, and so China and Iran are bound by that as well.

As is clear, the application by a state of its own definition of nationality may be inadequate for international law purposes. While it is clear that states may adopt, for national purposes, their own definitions of "nationality", it is also clear that international law reserves to itself the equivalent competence to determine how it will determine and define "nationality" for international law purposes. While a state has the sovereign right to apply its own definitions of nationality for municipal purposes, it must be obliged to apply the international law definition when it operates on the international plane.

For international law purposes, "nationality" is increasingly assessed upon an "effective nationality" basis. Once the effective nationality of the individual is determined, which would be a question of fact and not of law, then that individual's rights from an international law perspective can be determined and, if necessary, remedies applied.

So in the cases noted above, if "nationality" means "effective nationality" at an international law level, then a strong argument exists that by the failure of Iran and Chi-

\footnotetext{
129 Iran ratified the VCCR on 5 June 2975; China acceded to the VCCR on 2 July 1979. See: Multilateral treaties deposited with the Secretary-General. Disponível em: http://treaties.un.org/Pages/ ParticipationStatus.aspx. Acesso em: 26 nov. 2013.

130 VCCR supra, note 2, opening averments.

131 "Multilateral treaties Deposited With the Secretary-General", supra note 54 at: http://untreaty.un.org/ilc/texts/getter.asp. Canada is not a party and the United States has withdrawn from it.
} 
na to recognize, domestically, the adopted nationalities of Ms. Kazemi, Mr. Celil, Ms Zaghari-Ratcliffe and others they may have violated their international law obligations. ${ }^{132}$ Put another way, if effective nationality is the standard for nationality-based remedies under international law, then mistreatment of dual nationals may create openings for the assertion of claims under the rubric of Diplomatic Protection. Further, if China has effectively denied consular assistance to Mr. Kovrig and Mr. Spavor, for example, this may have violated another nationality based right at international law. Any claim arising from such a violation should not fail on the mere basis of the dual nationality of the victim.

Within that legal context, international law should apply this standard in cases of dual nationality when Diplomatic Protection is claimed as a remedy and when consular assistance is sought. Ultimately this becomes a question of fact. A tribunal would have to examine the life and situation of the individual in question to assess with which state such an individual had the closest links. Tests are suggested in Nottebohm and in a number of the individual cases before the Iran-United States Clai$\mathrm{ms}$ tribunal, but that is the subject for another paper.

\section{Conclusions and recommendations}

When individuals adopt a new nationality the vast majority of them, with the chance of a new beginning in a new land, undoubtedly do so with a sense of optimism and hope. It is likely that, once they have a new nationality, they expect to have the rights and protections of their fellow citizens. Yet through no fault of theirs or of their new nation's this may not be the case. If a person has left a country which neither recognizes dual nationality nor permits divestment of the birth nationality, their new nationality may not be recognized. Thus a return visit to the land of their birth, or to states with close connections with the land of their birth, may pose hazards. As Mr. Celil discovered, neither his Cana-

\footnotetext{
132 The problem does not arise when the dual national is detained in a country in which he/she is not a national. The recent case of Luis Carlos Cossio is an example. Cossio was detained by Venezuela in April 2010 in relation to suspicion of espionage. Cossio is a dual Colombia-Canadian national and, accordingly, Canada has sought to provide consular assistance on his behalf. To date there is no indication that Venezuela has denied access. See: El Universal, 9 Apr. 2010. Disponível em: http://calidaddevida.eluniversal.com/2010/04/09/ pol_ava_canada-solicita-visi_09A3718813.shtml. Acesso em: 27 nov. 2013.
}

dian nationality nor his presence in Uzbekistan, did not prevent his ending in a Chinese prison.

Individuals who take dual nationality should take the following precautions:

(i) ensure that you develop strong connections with the new state of nationality. Open bank accounts, buy a house, maintain steady employment and pay taxes; all of these things will assist in establishing that your dominant and effective nationality is the newly adopted one.

(ii) Be aware of the legal status of your new nationality vis-à-vis your original nation. Does it recognize dual nationality? If not will it allow consular assistance to be provided by the state of new nationality if necessary? You can find this out at your Ministry of Foreign Relations, or equivalent.

(iii) If your birth state does not recognize dual nationality and you do travel to your former homeland, register immediately with your embassy. Make sure they have a detailed itinerary of your trip, including contact information (phone numbers, emails etc). In the event of a problem you need to be sure that the embassy can find you or a contact person.

States, such as Canada, the United States, Australia and others, who accept many immigrants and have many dual nationals arguably have an onus to carefully advise their new citizens of the risks some of them may face in traveling to their former homelands, and the limitations on the ability of their new government to assist. $^{133}$

More delicate is the issue of the steps, which ought to be taken at the international level to clarify such issues. While states generally resist perceived interference in their internal affairs, it is clear that there is an international component to "nationality". States receiving large numbers of immigrants must decide if they are going to permit some countries to ignore their international obligations in this field to the detriment of their nationalized citizens. Craig Forcese, of the University of Ottawa has written that, within the Canadian context, the Canadian government should be subject to a legal obligation to assert diplomatic protection in all cases in which states refuse to acknowledge the dual nationality of a Canadian citizen. ${ }^{134}$ Logically, the same should apply to consular assistance. 133 The Australian Government, for example, provides informa-
tion to dual nationals via the Internet. See: http://www.smartravel-
ler.gov.au/tips/dualnat.html\#whats.
134 FORCESE, Craig. The obligation to protect: the legal context
for diplomatic protection of canadians abroad. University of New
Brunswick Law Journal, v. 57, p. 102, 2007 . 
Such steps, though possibly including actions at the International Court of Justice, could include interventions at the International Law Commission and in other international human rights tribunals.

Once granted nationality, new citizens have a reasonable expectation that they are on the same legal plane as their fellow citizens. If grants of citizenship are to be derogated from by the actions of other states and if those actions arguably are in violation of international law, then arguably the nationalizing state has a duty to take all steps necessary to clarify the issue for international law purposes as well as to defend the meaning of their own nationality. It is a duty they owe themselves because there is a need to uphold international treaties and to prevent anarchy. It would also seem to be a duty owed to their newest citizens.

\section{References}

AUDIT, Mathias. La coexistence de procédures contentieuses en matière d'investissements étrangers. Anuario Colombiano de Derecho Internacional (ACDI), v. 10, p. 333370, 2017.

BROWNLIE, Ian. Principles of public international law. 6. ed. Oxford: Oxford University Press, 2003.

CÓRDOVA, Roberto. Report on Multiple Nationality. U.N. Doc. A/CN.4/83, para. 8 .

DUCHESNE, Matthew S. The continuous-nationalityof-claims principle: its historical development and current relevance to investor-state investment disputes. Geo. Wash. Int'l L. Rev, v. 36, p. 783, 2004.

DUGARD, John R. First Report on Diplomatic Protection. UN Doc. A/CN. 4/506, 7 Mar. 2000. (hereinafter "First Report") and published in The Report of the $52^{\text {nd }}$ Session of the International Law Commission (2000) U.N. Doc. A/55/10.

FORCESE, Craig. The obligation to protect: the legal context for diplomatic protection of canadians abroad. University of New Brunswick Law Journal, v. 57, n. 102, 2007.

KÄLIN, Christian H. Key Contours of Citizenship and Ius Doni: Ius Doni in International Law and EU Law. Brill Nijhoff, 2019.

KETTNNER, James. Subjects or Citizens? A Note on
British Views Respecting the Legal Effects of American Independence. Va. L. Rev, v. 62, n. 945, p. 947, 1976.

KRAKAT, Michael B. Genuine links beyond state and market control: the sale of citizenship by investment in international and supranational legal perspective. Bond Law Review, v. 30, p. 145, 2018.

LEIGH, Guy I. F. Nationality and diplomatic protection. Int'l and Comp. L. Q, v. 20, n. 453, p. 456, 1971.

LIGABO, Ambeyi. Special Rapporteur. U.N. High Commission on Human Rights on the Right to Freedom of Opinion and Expression. Report on Mission to the Islamic Republic of Iran. 12 Jan. 2004. U.N. Doc. E/ CN.4/62/Add 2, para. 74.

LILLICH, Richard B.; BEDERMAN, David J. Jurisprudence of the foreign claims settlement commission: Iran claims. AJIL, v. 91, p. 436, 1997.

MACLEAN, R. J. Blaise. Fresh hay from old fields: the continuing usefulness of diplomatic protection. In: GALVIS, Ricardo Abello (ed.). Derecho internacional contemporáneo: lo público, lo privado, los derechos humanos: liberr amicorum en homenaje a Germán Cavelier. Rosario: Ed. Universidad del Rosario, 2006. p. 230-246.

MACLEAN, Robert Joseph-Blaise; AREVALO, Walter. The expulsion of resident colombian nationals during the Colombia-Venezuela border dispute: an under the radar: case for diplomatic protection of human rights?. Vniversitas, v. 68, n. 138, 2019.

MARTIN, David. New rules on dual nationality for a democratizing globe: between rejection and embrace. Geo. Imm. L.J., v. 14, n. 1, 1999/2000.

MCGARVEY-ROSENDAHL, Patricia. A new approach to dual nationality. Hous. J. Int. L., v. 8, p. 305, 1985/1986.

MUCHMORE, Adam I. Passports and nationality in international law. U.C. Davis J Int'l. L. and Pol'y, v. 301, p. $316,2003 / 2004$.

NUNES, Paulo Henrique Faria. Nacionalidade: novas regras, velhos problemas. Revista de Direito Internacional, Brasilia, v. 16, n. 2, p. 225-242, 2019.

PEREIRA, Hitala Mayara Pereira de Vasconcelos. Da nacionalidade como direito humano: da necessária ampliação das hipóteses de aplicação do critério do jus sanguinis nos casos de adoção internacional. Revista de Direito Internacional, Brasilia, v. 11, n. 2, p. 435- 
452, 2014/2015. DOI: http://dx.doi.org/10.5102/rdi. v11i2.3035.

RUBENSTEIN, Kim; ADLER, Daniel. International citizenship: the future of nationality in a globalized world. Ind. Global Legal Stud., v. 7, p. 519, 1999/2000.

RUSSELL, Franklin. Dual nationality in practice-some bizarre results. Int'l Lanyer, v. 4, p. 756, 1969/1970.

SCOT'T, Michael. Iran-United States Claims Tribunal: decision in Case A/18 concerning the question of jurisdiction over claims of persons with dual nationality. Harv. Int'l L.J., v. 26, p. 208, 1985.

SPIRO, Peter. Dual nationality and the meaning of citizenship. Emory Law Journal, v. 46, p. 1411, 1997.

WARBRICK, Colin. Diplomatic representations and diplomatic protection. ICLQ, v. 51, p. 723, 2000.

ZVONKO R. Rode. Dual nationals and the doctrine of dominant nationality. A.J.I.L., v. 53, n. 1, p. 139, 1959. 
Para publicar na Revista de Direito Internacional, acesse o endereço eletrônico www.rdi.uniceub.br ou www.brazilianjournal.org.

Observe as normas de publicação, para facilitar e agilizar o trabalho de edição. 